\title{
2006-513: INDUSTRIAL ETHICS TRAINING: A LOOK AT ETHICS GAMES
}

Marilyn Dyrud, Oregon Institute of Technology 


\title{
Industrial Ethics Training: A Look at Ethics Games
}

\begin{abstract}
Federal legislation mandates that US businesses develop ethics training programs for their employees. Starting in 1991 with the US Federal Sentencing Guidelines, which were revised in 1995, 1999, and 2004, and continuing through the Sarbanes-Oxley Act of 2002, passed in the wake of Enron, WorldCom, and other corporate scandals, businesses have had to implement ethics training or risk substantial penalties. Industry has responded to the challenge by initiating an impressive, and, in some cases, imaginative, array of compliance programs, and many have developed company-specific ethics games. This paper provides a snapshot of ethics games currently used for training in engineering-related US businesses, including a summary of federal guidelines provided by the US Sentencing Commission and the Sarbanes-Oxley Act, types of games currently available, efficacy of the games, and appropriateness for educational institutions.
\end{abstract}

\section{Introduction}

The business scandals of 2002 have changed the compliance world, thrusting into the media spotlight systemic problems with corporate ethics: namely, that codes of conduct do not necessarily result in ethical behavior and that some corporate bigwigs play by different rules. Enron, for example, touted a 64-page code of ethics, which the company required all employeesincluding management-to read and then sign an oath attesting to their commitment to high ethical standards. Enron took its ethics code very seriously, at least on paper, as noted in a 2000 memo penned by CEO Ken Lay: "I ask that you read them ["commonsense rules of conduct"] carefully and completely and that, as you do, you reflect on your past actions to make certain that you have complied with the policies. It is absolutely essential that you fully comply with these policies in the future." Similarly, Tyco's board of directors established as a goal "high standards of honesty, integrity, and ethics throughout the organization."2

Yet corporate lip-service to ethics did not prevent high-level personnel from ransacking employee pension funds and absconding with billions of ill-gotten dollars or, in the case of Tyco CEO Dennis Kozlowski, squandering substantial company revenues on questionable personal expenditures, such as the highly publicized $\$ 2$ million birthday bash for his wife on the island of Sardinia. ${ }^{3}$ The basic problem at Enron, notes former Motorola compliance officer Jim Brennan, was that "ethics didn't permeate the [corporate] culture sufficiently to alter the trajectory of the company." Ethics was for the worker bees and apparently did not apply to elite upper management, who were already commanding unconscionably high salaries and perks.

In response to the ethical indiscretions of Enron, Tyco, WorldCom, Imclone, World Crossing, Adelphia, Arthur Andersen, and a host of other high-profile companies, two major legislative acts were enacted: the Sarbanes-Oxley Act of 2002 and the subsequent 2004 amendments to the US Sentencing Commission's federal organizational sentencing guidelines. 


\section{Legislation}

Signed into law on July 30, 2002, the Sarbanes-Oxley Act (SOX) aimed to reduce questionable accounting practices in public companies that allowed the corporate scandals to occur. The law, which applies to any organization reporting to the Securities Exchange Commission, has some 66 provisions that include requiring organizations to establish a public oversight committee to regulate auditing procedures, mandating CEO certification of financial reports for "compliance and accuracy," and prohibiting alteration and/or destruction of corporate documents. ${ }^{5}$

SOX also encourages action on a number of ethics-related issues:

* Provide increased protection for whistle-blowers

* Adhere to an established code of ethics or explain reasons for non-compliance

* Engage in "full, fair, timely and understandable disclosure"

* Maintain "honest and ethical" behavior

* Report ethics violations promptly

* Comply with "applicable governmental laws, rules, and regulations"6

While SOX does not mandate developing a code of ethics and employee training programs, it strongly encourages these actions.

The passage and implementation of SOX resulted in concomitant amendments to the Federal Sentencing Guidelines, with one crucial difference: what SOX encourages, the guidelines mandate. Chapter 8, Part B, Section 2 of the 2004 guidelines requires all organizations, including non-profits, to develop and implement an "effective compliance and ethics program" designed to meet two goals: "exercise due diligence to prevent and detect criminal conduct, and otherwise promote an organizational culture that encourages ethical conduct and a commitment to compliance with the law."7

Formed in 1985 as an independent agency of the Department of Justice, the US Sentencing Commission was charged with developing consistent standards for sentencing in federal court; these became effective in 1987. In 1991, the commission introduced organizational sentencing guidelines, which included a compliance provision, offering businesses incentives to investigate, report, and take steps to prevent criminal behavior by all agents of the organization, including management. $^{8}$ The guidelines' goal was "to encourage good corporate citizenship" and empowered sentencing courts to impose fines of millions of dollars for non-compliance. ${ }^{9}$

According to the 2004 amendments, an effective program must include, at minimum, these seven elements:

1. Standards and procedures to prevent and detect criminal conduct

2. Responsibility at all levels of the program, together with adequate program resources and authority for its managers

3. Due diligence in hiring and assigning personnel to positions with substantial authority 
4. Communicating standards and procedures, including a specific requirement for training at all levels

5. Monitoring, auditing, and non-internal guidance/reporting systems

6. Promotion and enforcement of compliance and ethical conduct

7. Taking reasonable steps to respond appropriately and prevent further misconduct in detecting a violation ${ }^{9}$

The amendments also pointedly address the role of management: "High-level personnel of the organization shall ensure that the organization has an effective compliance and ethics program."7 Leadership commitment to ethics is essential, as Stephen D. Potts, former director of the Office of Government Ethics, has emphasized: "The leader must incorporate ethics into his or her speeches at staff meetings, as well as communicate its importance throughout the organization. The leader must also lead by example. Employees do watch how their leaders behave." 10

And, finally, the guidelines require periodic risk assessment and outcomes-based program evaluation. ${ }^{\text {? }}$

\section{Industry Response}

Initial response to the 1991 guidelines was, for the most part, conventional: ethics offices and hotlines sprouted up; more progressive companies, such as Martin Marietta, established ethics awareness training programs for all employees. However, the guidelines were less effective than anticipated: between 1991 and 1995, 280 companies were sentenced under the organizational guidelines, most for fraud, antitrust, environmental, or tax violations, and a 1993 National Law Journal survey of corporate counsels revealed that fully two-thirds of companies surveyed had violated various federal regulations. ${ }^{11}$

With the 2004 amendments to the guidelines, industry has stepped up its response in imaginative ways. While many, Honeywe $11^{12}$ and the Harris Corporation ${ }^{13}$ for example, still use conventional approaches to ethics training, such as short live or Web-based courses developed by consulting companies specializing in tailor-made ethics and compliance programs, others are capitalizing on contemporary game theory in an effort to psychologically invest employees in the business of ethics. According to J. C. Kinnamon, vice-president of product development for Midi program supplier, game-based programs "can boost learner interest and content retention."

\section{Types of Games}

Industrial ethics games, some of which pre-date the 2004 sentencing amendments, run the gamut from relatively simplistic short scenarios to complex role-playing simulations and use a variety of environments, including paper, face-to-face discussion formats, Web-based, and PC-based. They fall under the general category of "serious games," those designed for more than entertainment; they "impart a lesson or point of view." 15 
In these games, employees respond to mini-cases, either via the Web or face-to-face. Bell South's "Brief Cases" is a good example of a Web-based short scenario game. Employees can select statements from a menu of categories-employee behavior, government issues, business practice, contractors/suppliers, human resources, accountability for company property, or conflict of interest-and must choose one of several responses. The site features "daily specials," such as "bringing your pistol to the office," on the opening page. A sample case is shown in Figure 1.

\section{Ethics Scenarios Game}

You suspect a co-worker has been drinking alcohol on the job.

The best answer is:

A) Notify your supervisor of your suspicions

B) Approach the coworker and discuss the situation

C) Ignore the situation. It's a personal issue

Figure 1. Example of Bell South Web-based game ${ }^{16}$

Feedback is instant: for both correct and incorrect responses, the correct answer and a rationale is displayed (see Figure 2).

\section{Ethics Scenarios Game}

Employee Behavior

You suspect a co-worker has been drinking alcohol on the job.

The best answer is:

A) Notify your supervisor of your suspicions

Rationale: Employees are required to report this situation to management as soon as possible (to avoid personal injury or damage to company property). Approaching the coworker on a personal level may be an option and would give him or her the opportunity to take care of the problem. If you are not comfortable talking to the worker, get the appropriate management person involved. Remember that Bell South has an Employee Assistance Program (EAP) to help employees with such problems.

Figure 2. Corporate response 16

Governmental regulatory agencies got an early start on game development; in 1994, the Office of Government Ethics released "Dangerous Dilemmas" for employee ethics orientation. The teambased game consists of 20 scenarios with multiple choice-answers. According to Cecilia Owens, 
then acting associate director of education, players "will develop a basic knowledge of the standards of conduct and learn correct ethical actions is some common workplace situations." The game was also used for pre- and post-testing to measure employees' knowledge of federal ethics guidelines. ${ }^{17}$

Of companies involved in short scenario-based gaming, one stands apart: Lockheed-Martin has expended considerable resources over the past dozen years in developing scenario-based games, starting with "Gray Matters" in the early 1990s, which featured 100 scenarios to illustrate corporate values. ${ }^{18}$ "Gray Matters" morphed in "The Ethics Challenge," debuting in 1997 and featuring characters from the Dilbert comic strip.

"The Ethics Challenge" is a full-flown board game that involves group dynamics and discussion as players respond to short cases illustrating Lockheed-Martin's six corporate values: honesty, integrity, respect, trust, responsibility, and citizenship. Players are encouraged to consider the company's four-point ethical decision-making model as they deliberate:

1. Evaluate information

2. Consider how your decision might affect stakeholders

3. Consider what ethical values are relevant to the situation

4. Determine the best course of action that takes into account relevant values and stakeholders' interest ${ }^{19}$

Play is simple, to allow for a one-hour time slot. Groups of players choose a game pieceDilbert, Wally, Ratbert, Catbert, The Boss, or Alice-that they move around the board locations: boss's office, cafeteria, cubicles, conference room, parking lot, lobby, production, and water cooler, each of which has tokens. Movement is determined by points assigned to the scenario responses (see Figure 3).

Dogbert serves as an ironic commentator for each case, and landing on a Dogbert space during play allows the team to choose a Dogbert "Coffee Break" card, which either confers a reward"For telling the best joke at the staff meeting, go to the Conference Room and collect one token"-or metes outs punishment-"Failure to return a borrowed stapler, donate one token to the team on your left."

The team that collects the most tokens wins. Actually, though, everyone wins: for at least an hour, employees have been engaged in focused problem-solving and consensus-based discussion about corporate scenarios based on real ethics cases at the company.

Each game set includes all playing accessories; a video of opening/concluding remarks by CEO Norm Augustine, Dilbert, and Dogbert; six team guides; and one very detailed leader's guide. This booklet includes instructions for play, a guide for determining numbers and sizes of groups, a floor plan for optimal table arrangement, and comments on the potential answers for each scenario, including scores for each response. 


\section{File CASE Number: 32 \\ Category: Retaliation \\ Target audience: All employees \\ Setting the Standard: Respect}

You saw your manager playing computer games on his PC during working hours, and reported this to the company Ethics Officer. The Ethics Office notified you that the allegation was substantiated and appropriate action would be taken. Although your manager has not said so, you believe he suspects you were the originator of the allegation, because your desk is closest to his. You recently had your performance review and for the first time ever, you did not receive a salary increase. You strongly suspect this is retaliation. What should you do?

\section{Potential ANSWERS:}

A. Do nothing.

B. Raise your concern with Human Resources.

C. Go back to your company Ethics Office, and tell them you believe you are the victim of retaliation.

D. Raise the retaliation issue with your manager as part of your performance feedback discussion.

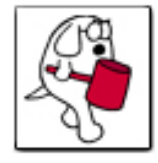

Offer to report your co-workers so the investigation won't focus on him.

Figure 3. Example of a Lockheed-Martin scenario ${ }^{19}$

Of all the ethics games surveyed for this paper, Lockheed-Martin's are the most comprehensive, partly because of the obvious attention paid to detail and partly because the company games reflect the philosophy of leader Norm Augustine, that "ethics are not binary-they are analog. It would of course be convenient to conclude that ethics are absolute...that everything is either Right-or it is Wrong. Zero...or one. Binary. Unfortunately, life does not seem to be that simple." 20

Lockheed-Martin's most recent foray into ethics gaming is "Ethics Matters," which debuted in 2004. It is a card game which includes short scenarios gleaned from company files, news headlines, and what they call "advanced cases," some of which have an international component.

Play consists of teams choosing cards and discussing the cases based on a number of ethics questions/issues; each case includes a main character who decides between various courses of action, such as whether or not accepting lavish hotel quarters for an out-of-town meeting violates company policy on gifts and gratuities. The team chooses an action and then rates the response on the "Ethics Meter" (Figure 4). 
Highly Unethical: The worst choice, a potentially serious ethical lapse, could include illegal acts

Unethical: An inappropriate solution, a clear violation of ethics principles

Gray Area: A more neutral option, not clearly ethical or unethical

Ethically Sound: A viable option, clearly ethical, not necessarily the most ethical solution

Highly Ethical: The most ethical solution; may go above and beyond policy compliance; demonstrates the highest personal integrity

Figure 4. Lockheed-Martin's "Ethics Meter,"21

Games based on short scenarios have the virtue of time; since most are developed for one-hour, it is possible to have multiple training sessions annually, rather than stuff everything into one very full day. Short intense learning sessions may, indeed, increase employee awareness of ethics as a daily workplace concern.

\section{Simulation Games}

Simulation ethics games are more complicated than those described above, as they "recreate" a business and usually are computer-based. Most reflect a video game model and include avatars and levels, in an attempt to capitalize on the contemporary predilection for electronic gadgetry. In 1997, the Department of Justice developed "Quandaries," a PC-based arcade-type game which players download to their individual PCs. The game constitutes ethics awareness training for the more than 10,000 DOJ employees who must file public or confidential financial disclosure reports. $^{22}$ The game is based on vignettes from actual DOJ ethics cases. Players choose either an administrative, legal, or management pathway and follow their avatar through daily routines in up to five levels per pathway. The goal is promotion, and only avatars which demonstrate enough knowledge of federal ethics rules are eligible. ${ }^{23}$ Correct ethical choices determine success.

Some simulation games are generically corporate and therefore useful in virtually any industrial setting. "Up the Corporation," developed by Glass Ceilings Productions in 2004, combines board and card play. ${ }^{24}$ It includes eight stereotyped characters, such as Bernie Brown Nose, who follows the CEO "like a puppy"; Suzie Do Right, who "tries hard to impress upper management with her knowledge and expertise"; and Dan the Drone, the organization's "workhorse." Annalee Airhead, the office sex kitten, is shown in Figure 4.

To commence play, each employee chooses a character piece and then draws education and salary cards to determine order of play. Players then draw strategy cards from one of three categories (hard work, politics, and ethics) and must make correct decisions to advance up the corporate ladder. Overall game play derives from the childhood classic, "Chutes and Ladders," 


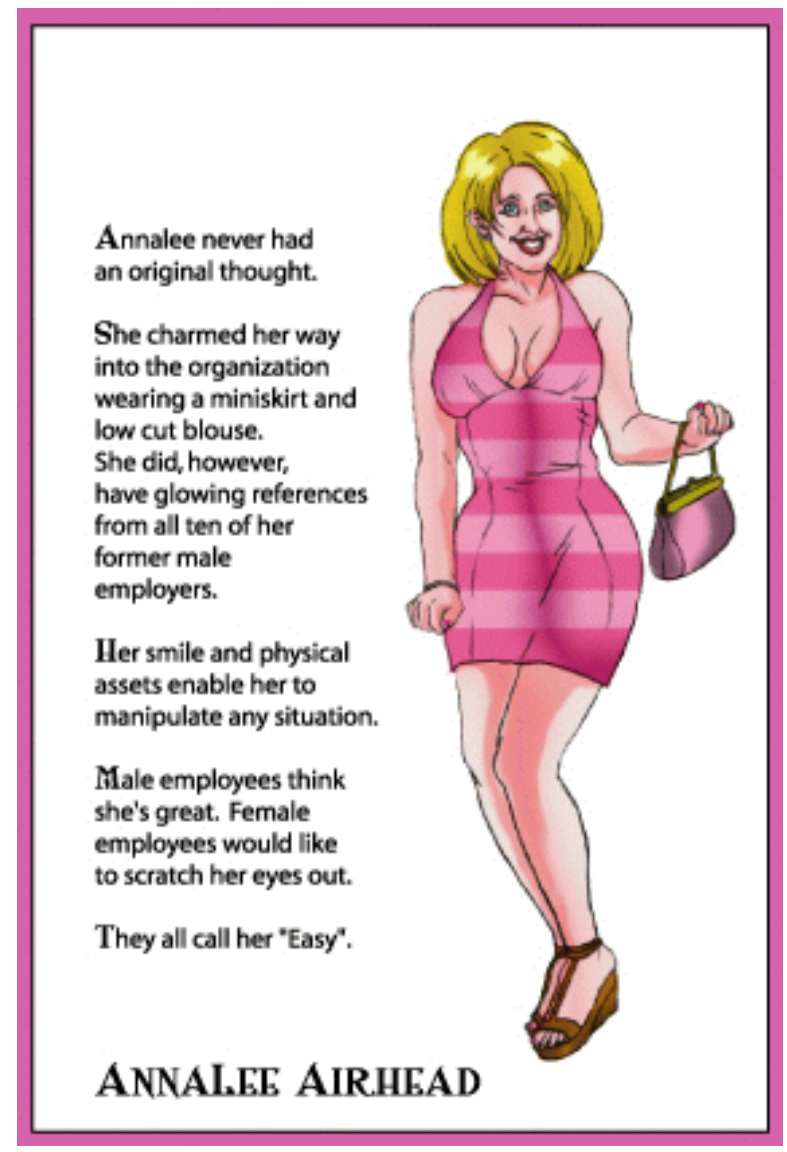

Figure 4. "Up the Corporation" character ${ }^{24}$ and card scenarios are drawn from facts and anecdotes about corporate life. Annalee, for example, is caught Internet shopping at work and forfeits her next promotion.

The game, notes reviewer Darren Garnick, "delightfully tackles some lower-profile human resources issues" and is reality-based, "repeatedly point[ing] out that sometimes hard work alone just doesn't cut it." 25 Unlike the Lockheed-Martin games, which require group interaction and consensus, "Up the Corporation" is more cutthroat: players are out for their own good.

The game also has a "vent" function at the website, so players may offer comments about the characters in their own real work settings. A disclaimer notes that these may or may not be used in the next version of the game.

Sim City has had a major impact on computerized simulation games. "Executive Challenge" is a three-day video simulation used at the University of Texas at Austin to introduce MBA students to ethical decisionmaking processes and procedures. Players are

divided into three different companies and each player has a specific role within the virtual firms. A wrong decision could result in disaster. In one scenario, for example, a firm's ethics officer avatar "killed" 350 employees after making the decision to continue production at a virtual plant in Indonesia, which had been repeatedly threatened with terrorist actions. Notes game developer Allen Varney, "The game is all about temptation.",26

\section{Quick Takes}

Not all ethics games are time-consuming. Abbott Laboratories has implemented "Rocked or Shocked," a touch-screen game played at kiosks set up during training sessions or corporate meetings. ${ }^{27}$ Players have a minute to answer six questions, such as "When it is appropriate to accept baseball tickets from clients" from a rotating database. Players control avatar Joe Salesguy: a wrong answer delivers an electric jolt that melts Joe into a "charred lump," while a right answer results in a smile and tie-straightening. ${ }^{28}$

Although Abbott introduced the game as a way to add more excitement to ethics training sessions, one side effect is that players frequently give wrong answers simply to watch Joe dissolve into a sizzling heap. ${ }^{28}$ But, notes Abbott's director of external communications, Ann 
Fahey-Widman, the game is meant "as a reinforcing diversion and not a serious test of mastery." 27

\section{Individual-Oriented Games}

While many ethics games currently in use take place in a group face-to-face setting, some organizations have developed tactics for individual play or advice. The Ethics Resource Center has available for general distribution ethics-related crossword puzzles and word search gamesbasically brain teasers to test individual knowledge. ${ }^{29}$ Other organizations, such as Bell South, offer quick ethics "self-tests," that offer short checks on proposed behavior: "Am I being fair and honest; will my actions stand the test of time; will I sleep soundly tonight; and would I tell my children to react in the same way."16

Northrop Grumman has instituted "test yourself awareness guides" as part of an ethics "refresher" program. Employees can access short pamphlets or policy statements in a number of different areas, such as export/import controls; the Foreign Corrupt Practices Act; kickbacks, gratuities, and conflicts of interest; procurement integrity; or supplier relationships. ${ }^{30}$ Employees can read the information and then take a short test at the end. The "Kickbacks, Gratuities, \& Conflicts of Interest" pamphlet, for example, defines relevant terms, explains responsibility, and gives guidelines for regular and supervisory personnel. The yes/no self-test asks questions such as "You are going to a conference hosted by a supplier which will have clients from other companies in attendance as well. May you accept a meal? How about travel and hotel expenses?" Conflicted employees can access the answers at the end of the test.

Ethics advice columns are also creeping into corporate publications. The State of Washington, for example, has incorporated a short ethics column into its employee newsletter, featuring a generic sauropod, "Professor Ethosaurus," who responds to employee queries such as the following: "I am a state employee and my supervisor is running for a state office. Every morning he asks me to check the polls on the Internet to see how he's doing. I don't think I should be doing this and told my supervisor so. He said do it anyway. Is this an ethics violation for either one of us?" The response: "This activity and conduct of both individuals violates the Ethics in Public Service Act. Specifically, RCW 42.52.180, which prohibits the use of state resources, including the knowing acquiescence of a supervisor, to promote or oppose an initiative or candidate for public office." 31

\section{Efficacy}

Lockheed-Martin is recognized as having one of the most vibrant and effective corporate ethics programs, attributable to several characteristics: treating employees as peers; mandating programs for every employee; using past company-specific ethical breaches as a basis for current training; allowing for anonymous input, as well as providing multiple channels; and taking decisive action. ${ }^{32}$ Add to the mix a CEO who is truly invested in responsible corporate behavior (Norm Augustine was the founding chairman of the Ethics Resource Center), ${ }^{33}$ and the result is success. And Lockheed goes a step further, with an annual employee Ethics Film Festival and company awards and recognition for ethical behavior. ${ }^{34}$ 
Overall, however, literature regarding efficacy of gaming techniques as part of an ethics and compliance program is sparse, partly due to the newness of the genre and partly due to the relative newness of the assessment and reporting requirement under the Federal Sentencing Guidelines' amendments. "The Ethics Challenge" game, however, has been the focus of perception testing by Jim Lyttle, as reported in the Journal of General Psychology. The use of cartoon characters, particularly Dogbert's ironic commentary, affects participants' attitudes towards the game, according to Lyttle's exploration of humor in persuasion. ${ }^{35} \mathrm{He}$ concludes that “"The Ethics Challenge' was a very effective instrument for persuasion," specifically in encouraging employees to increase contact with the organization's Ethics Office.

Although empirical data from industry are currently lacking, research into the use of gaming in educational institutions provides some information regarding effectiveness. Kristen Monroe, director of the ethics center at University of California, Irvine, suggests that computer games, in particular, "can encourage empathetic involvement," 36 an attribute essential for the leaders of tomorrow. Gordana Dodig-Crnkovic and Thomas Larsson, Swedish scholars who teach computer engineering at Mälardalen University, have examined the influence of gaming in general and concluded that "computer games...are powerful tools able to change our ideas about the world and our agency in it." 37 And, as reported by the Northwest Regional Educational Laboratory, educational games offer these specific benefits:

* Result in a deepened understanding and sharing with others

* Teach competition strategies and group dynamics skills

* Offer high involvement and motivation

* Provide immediate feedback

* Provide experiences learning "crisis-management, communication and problem solving, data management, and collaboration",38

Whether or not ethics games are more effective than live intensive sessions is still to be determined. Judging by the educational literature, however, games have the virtue of appealing to different learning styles and are much more cost-effective than hiring high-priced outside consulting firms to develop programs, an ironic side effect of the mandated ethics and compliance provision.

\section{Educational Appropriateness}

Industrial ethics games can be a boon to the classroom, for not only do they reinforce the notion with students that business and industry care about ethics (indeed, now they are required to care about ethics!), but the games offer insights into organizational structure, which, for most traditional-aged college students, is truly new information.

As an eight-year veteran of using "The Ethics Challenge" in a variety of classes, including a civil engineering senior-level capstone design project, I can say with certainty that this game is a delight in the classroom! Not only is it different from the typical classroom routine, but students are surprised at the hierarchical arrangement of Lockheed-Martin, especially the notion of reporting virtually everything to someone. Table I clearly shows that the high-counting answers 
in the game scenarios involve reporting to supervisors or others higher up in the corporate food chain. Of 50 scenarios, only two "right" answers involve speaking to the person involved. This is definitely a change from the flatter educational organization that students have become accustomed to.

Table I. "The Ethics Challenge" highest score case solutions

\begin{tabular}{|l|l|l|l|}
\hline \multicolumn{1}{|c|}{ Reporting venue } & Number & Percentage & \multicolumn{1}{c|}{ Case file numbers } \\
\hline Supervisor/manager & \multicolumn{1}{|c|}{22} & 44 & $\begin{array}{l}2,4,10,11,14,15,19,20,24,26,27,28,29, \\
33,35,41,43,46,47,48,49,50\end{array}$ \\
\hline Ethics Office/HR & 11 & 22 & $3,7,13,16,18,22,32,37,39,40,44$ \\
\hline Legal counsel & 4 & 8 & $1,17,21,36$ \\
\hline Other personnel & 6 & 12 & $5,8,12,25,30,42$ \\
\hline Other action & 7 & 14 & $6,9,23,31,34,38^{*}, 45$ \\
\hline
\end{tabular}

* Recommends two possible actions

Playing "The Ethics Challenge" offers students and instructors a refreshing change, especially from lecture-oriented classes. The opening video explains all games rules, and instructors need only to separate the class into groups, provide each group with necessary items for play, and serve as session leader. While the game fulfills the practical function of helping to meet the ABET criterion involving an understanding of professional and ethical conduct, discussions of the scenarios can highlight potential ethical conflicts and lead to considerations of larger issues.

Case 42, for example, allows students to discuss the difference between a suspicion and a fact: "While leaving the plant on your lunch break one day, you notice a friend of yours smoking in the company parking lot, and it smells like marijuana. You know this person is not a cigarette smoker. Your friend happens to work in a classified production area. How would you handle this situation?"19 The highest-scoring response is to "go directly to Security and report what you saw."

My students, however, are uncomfortable with this response, mainly because the worker would reporting a suspicion, not a verifiable fact. That the alleged violator is also a friend complicates the situation, as does Lockheed-Martin's drug-free workplace policy. ${ }^{39}$ This case thus provides fodder for some fairly energetic class discussion regarding drug testing in the workplace, as well as considerations of the appropriate time to report an infraction. In this case, reporting a suspicion of smoking marijuana could lead to significant action against the friend. Perhaps, my students suggest, it would be better to approach the friend directly for details of the situation, rather than immediately reporting it to Security. 
Case 44 also has potential for discussions of larger issues: "You receive an e-mail message from an employee in your division. Attached to the message is a link to a pornographic Web site. You notice the message has also been distributed to at least 30 other people in the company. You should...."19 Once again, the highest-scoring choice involves reporting the incident, in this case, to Lockheed's Ethics Office.

This case intrigues my students, primarily because of the computer angle and, of course, the fact that so much spam they receive involves sex. The case offers instructors the opportunity to introduce a discussion of common workplace procedures: most students understand that their employer owns the computer equipment, but they may not realize that the company also owns the information on it. It is important, therefore, that they familiarize themselves with corporate "acceptable use" policies regarding issues such as sending personal email, IMing, or blogging on the job.

Another current computer-related issue that students may not fully appreciate is that $76 \%$ of private industries in the US monitor employee Web usage using surveillance software. Indeed, according to a 2005 survey conducted by the American Management Association and The ePolicy Institute, 51\% of companies surveyed have fired workers for misuse of either the Internet or email. ${ }^{40}$ Nancy Flynn, ePolicy's director, notes that "Workers' e-mail, IM, blog and Internet content creates written business records that are the electronic equivalent of DNA evidence," which can be subpoenaed in the event of litigation.

Other games can also offer insight into corporate structures and conduct codes. While "Up the Corporation" is a physical board game, the website has a demo that students can work through, complete with sample scenarios and questions. "Professionalism and Ethics Simulation," an award-winning Canadian game dealing with agrology, can be played online. Players interact with goateed financial consultant Adam Smith, who, even as a cartoon character, seems rather personable. Adam poses various sticky questions, followed by an answer box; answers determine his follow-up conversation. Although agricultural engineering is not as popular an academic field in the United States as it is in Canada, it is enlightening for students to work through the ethics test following the game; even though the field is different, the expectations for professional behavior are virtually identical to other engineering areas.

\section{Conclusions}

Ethics games-indeed ethics training sessions in general-are most effective when applied to management as well as workers. Notes Kevin Cashman, head of a leadership consulting firm, "When leaders split off principles and purpose from profit and performance, the consequences can be devastating, as we've seen in the past few years." 34 Games based on actual scenarios or cases from the company, rather than hypotheticals, seem to make the most impact on players.

Even though the Sarbanes-Oxley Act, coupled with the new amendments to the Federal Sentencing Guidelines, have forced companies to be more conscientious about ethics training, those which develop games have gone the extra mile. 
Are ethics games the wave of the future? Possibly: they appeal to a basic human impulse-the urge to play-and offer a very different approach to ethics training. They are also useful in education, as we prepare the engineers of tomorrow. As game designers Dan Bunten and Heidi Aycock explain, "When you become completely absorbed by a game that pushes you to your intellectual edges, you feel like what you've done is more deeply significant than what you would have done otherwise. Good games are good for you. Fun is a vitamin for the mind, essential nourishment for your intellect." 42

\section{References}

1. Lay, Ken. Enron Interoffice Memo. July 1, 2000. Retrieved from http://www.thesmokinggun.com/enron/ enronethics2.html.

2. Tyco. Who We Are. 2004-2005. Retrieved from http://www.tyco.com/livesite/Page/Tyco/Who+We+Are/ Overview/.

3. Jurors See Tape of Kozlowski's Party. October 29, 2003. Retrieved from http://money.cnn.com/2003/10/28/news/companies/tyco_party/.

4. Martinek, Paul J. "Focus Should Be on Ethics Program Outcomes, Not Process." Compliance Week (June 7, 2005).

5. Lakey, Berit M. “Sarbanes-Oxley: When Accounting Comes Knocking.” Ethics Today Online, 2, no. 2 (October 2003). Retrieved from http://www.ethics.org/resources/articles_detail.cfm?ID=833.

6. ELT. Ethics \& Code of Conduct. n.d. Retrieved from http://www.elt-inc.com/solutions/ethics_and code_of_conduct_training_obligations.html

7. USSC. Chapter 8-Part--Remedying Harm from Criminal Conduct, and Effective Compliance and Ethics Programs. 2004. Retrieved from http://www.ussc.gov/2004guid/8b2_1.htm.

8. Courtander, Michael. Panel on the Sentencing Guidelines for Organization Issues Final Report. US Sentencing Commission. October 8, 2003. Retrieved from http://www.ussc.gov/PRESS/rel100803b.htm.

9. Federal Sentencing Guidelines. n.d. Retrieved from http://www.ethics.org/ethicsindex/ fsgo.html.

10. "Ethics in the Public Sector: Interview with Stephen D. Potts." Business of Government (September/October 1998): 3, 11.

11. Greenlee, Janet S., and David Bukovinskyln Brief. "Voluntary Compliance: Protection or SelfIncriminating Road Map?" The CPA Journal (August 1997). Retrieved from http://www.nysscpa.org/cpajournal/ 1997/0897/aug/F32897.htm.

12. Honeywell, Inc. General Management and Business Skills-Honeywell Values. n.d. Retrieved from http://content.honeywell.com/training/MaterialOnLine/Roadmap/CoreRoadmap/GenMgmtBusSkills/ HwllValues.asp. See the Thomson Learning site for a description of Honeywell's required business ethics course (http://www.netg.com/Catalog/detail.asp? $\mathrm{p}=3 \& \mathrm{~s}=572 \& \mathrm{t}=2726 \& \mathrm{c}=\mathrm{US} 41072 \& \mathrm{pStatus}=\mathrm{A}$ ).

13. Harris Corporation. Standards of Business Conduct. January 2005. Retrieved from http://www.govcomm. harris.com/suppliers/current/domestic.pdf.

14. "Do Games Have a Place in Compliance Training?" TrainingMag.com (November 1, 2005). Retrieved from Lexis-Nexis database. 
15. Lewis, James. “Gaming Take Serious Turn.” New Media, 8, no. 17 (September 16, 2005). Retrieved from http://www.zap.ca/nsmseriousgames.htm.

16. Bell South, Office of Ethics and Compliance. Ethics Scenario Game. 1995-2004. Retrieved from http://ethics.bellsouth.com/gamesandscenarios_ethicsscenariosgame_java.htm.

17. Owens, Cecilia. "Dangerous Dilemmas," An Ethics Training Game. June 24, 2004. Retrieved from http://www.usoge.gov/pages/daecograms/dgr_files/1994/dt94028.

18. Online Ethics Center for Engineering and Science. Mini-Cases from Lockheed-Martin Corporation. 19952004. Retrieved from http://onlineethics.org/corp/graymatters/martin.html.

19. Lockheed-Martin Corporation. Leader's Guide. Westlake Village, CA: Lockheed Martin, 1998.

20. Augustine, Norman R. "Ethics and Business: An Oxymoron?" Ethics Today Online, 3 no. 5 (February 2005). Retrieved from http://www.ethics.org/resources/speech_detail.cfm?ID=869.

21. Lockheed-Martin Corporation. The 2005 Ethics Effect. 2005. Retrieved from http://www.lockheedmartin. com/data/assets/9915.pdf.

22. Lais, Sami. "Justice Creates Video Game That's Ethical to Play on the Job." Government Computer News, 16, no. 20 (July 21, 1997). Retrieved from http://appserv.gcn.com/cgi-bin/udt/im.display.

23. Department of Justice, Departmental Ethics Office, Justice Management Division. Introduction to Ethics Training Program. n.d. Retrieved from http://www.usdoj.gove/jmd/ethics/ quandary.htm.

24. Glass Ceiling Production. Up the Corporation. 2004. Retrieved from http://www.upthecorporation.com/.

25. Garnick, Darren. "Games Mixes Adult Grips with "Chutes and Ladders." The Boston Herald (November 23, 2005): 32 .

26. McCartney, Jason. "Business Simulation Tests Ethical Decision-Making.” Wall Street Journal Online (December 1, 2005). Retrieved from http://www.collegejournal.com/mbacenter/newstrends/ 20040601mccartney.html.

27. Compton, Jason. Abbott Laboratories Shocking Ethics Gambit. September 23, 2004. Retrieved from http://www.destinationcrm.com/articles/default.asp?ArticleID=4459\&TopicID=10.

28. Kary, Tiffany. "Ethics: Code of Conduct." Psychology Today (January/February 2005). Retrieved from http://www.psychologytoday.com/articles/pto-20050301-000001.html.

29. Ethics Games and Puzzles. n.d. Retrieved from http://www.ethics.org/publications/games.html.

30. Northrop Grumman. Training Information and Requirements. 2005. Retrieved from http://www.es. northropgrumman.com/Our-Values/training.htm.

31. News Flash from the Executive Ethics Board. Summer 2004. Retrieved from http://ethics.wa. gov/newsletters/Summer2004.htm.

32. Fandray, Dayton. “Lockheed Martin: Putting Words into Action.” Workforce, 79, no. 12 (December 2000): 76. Retrieved from http://www.workforce.com/archive/feature/22/26/08/223473.php.

33. Ethics Resource Center. Annual Report, 2003. Retrieved from http://www.ethics.org/pdfs/ 2003_annualreport.pdf. 
34. Zelinski, Dave. “Can Ethics Save Your Company?” June 1, 2005. TrainingMag.com/Dolce International. Retrieved from http://www.dolce.com/meetings/article-037-can-ethics-save-your-company.php.

35. Lyttle, Jim. "The Effectiveness of Humor in Persuasion: The Case of Business Ethics Training." Journal of General Psychology, 128, no. 2 (April 2001): 206-16.

36. Monroe, Kristen. "Teaching Ethics through Empathetic Involvement." n.d. Retrieved from www.socsci.uci.edu/ethicscenter/pdf_documents/teaching_ethics_through_empathic_involvement.pdf.

37. Dodig-Crnkovic, Gordana, and Thomass Larsson. "Game Ethics-Homo Ludens as a Computer Game Designer and Consumer." International Journal of Information Ethics, 4 (December 2005). Retrieved from http://www.idt.mdh.se/personal/gde/work/Homo_Ludens_Ethics-IJIE.pdf.

38. Northwest Regional Educational Laboratory. "Simulations and Games." n.d. Focus on Effectiveness. Retrieved from http://www.netc.org/focus/strategies/simu.php.

39. Lockheed-Martin Corporation. Compliance Education \& Training: Drug-Free Workplace. October 6, 2000. Retrieved from http://www.lockheedmartin.com/data/assets/556.doc.

40. American Management Association. 2005 Electronic Monitoring \& Surveillance Survey: Many Companies Monitoring, Recording, Videotaping-and Firing-Employees. May 18, 2005. Retrieved from http://www.amanet.org/PRESS/amanews/ems05.htm.

41. Zapdramatic Case Study \#1 : Professionalism and Ethics. 2005. Retrieved from http://www.zap.ca/ casestudy1.htm.

42. Good Games Are Not a Waste of Time. 1992. Retrieved from http://www.randomterrain.com/ gamedesign/time.html. 